\title{
The Modifying Effect of Co-Mutagens on the Frequency and Spectrum of Radiation-Induced Chromosome Aberrations in Human Cells
}

\author{
Domina E, Pylypchuk $\mathbf{O}$ and Mikhailenko V*
}

R.E. Kavetsky Institute of Experimental Pathology, Oncology and Radiobiology, NAS of Ukraine, Kiev, Ukraine

\begin{abstract}
We have studied the co-mutagenic effect of verapamil and ascorbic acid on formation of radiation-induced chromosomal aberrations in T-lymphocytes of peripheral blood (PBL) of healthy donors. Test system of PBL treated in vitro with subsequent metaphase analysis of chromosomal aberrations has been used. Cells were exposed to $y$-ray radiation in $\mathrm{G}_{0}$ - and $\mathrm{G}_{2}$ - periods of cell cycle and treated with verapamil $(1.5 ; 2$ and $4.0 \mu \mathrm{g} / \mathrm{ml}$ of blood) and ascorbic acid (20; 40 and $80 \mu \mathrm{g} / \mathrm{ml}$ of blood). The post-irradiation treatment of PBL with ascorbic acid in concentrations of 40 and $80 \mu \mathrm{g} / \mathrm{ml}$, which exceeded therapeutic concentration value 2 and 4 times, increased overall chromosome aberrations frequency in 1.4 times compared to low dose $(0.3 \mathrm{~Gy})$ radiation effect. Verapamil at a concentration of $4.0 \mu \mathrm{g} / \mathrm{ml}$ also increased the damaging effect of low dose of radiation in 1.5 times. Modification of radiation-induced cytogenetic effects in human PBL treated with co-mutagens was dependent on the concentration of the drugs, the absorbed dose of radiation, as well as cell radiosensitivity. It could be concluded that high concentrations of comutagens potentiate the damaging effect of low doses of ionizing radiation.
\end{abstract}

Keywords: Co-mutagen; Peripheral blood lymphocytes; Chromosomal aberrations; Verapamil; Ascorbic acid; Ionizing radiation

\section{Introduction}

There is some uncertainty in the impact assessment of physical and chemical factors on human cells. Uncertainty becomes even more pronounced in case of successive action of agents [1]. This concerns primarily the co-mutagens, since their impact on the human genome is one of the important components of primary cancer prevention [2]. The co-mutagenesis is a phenomenon that contributes to the burdening of human genetic load, and can be interpreted as the effect potentiation [3].

In 1962, Taylor JH et al. found that the inhibitor of DNA synthesis fluorodeoxyuridine increased the yield of chromosomal aberrations, induced by irradiation in counterfoils beans [4]. In 1978, Lychnik N.V. introduced the term psevdomutagen referred to chemical agents that "increase the yield of mutations not by inducing new local damage in the chromosomes, but by inhibiting the repair of spontaneous (or those caused by another mutagen) hidden damage, which in its absence would be repaired" [5]. According to the modern concepts, the process of psevdomutagenesis is treated as co- mutagenesis [3].

Co-mutagens are compounds that, while not having own mutagenic properties can significantly modify (enhance) effects of known mutagens of chemical nature. Drugs with co-mutagenic properties remain insufficiently investigated, since lack of own mutagenic activity making them difficult to detect at genotoxic screening [6,7]

It was shown that calcium antagonist - verapamil $(\mathrm{Vp})$, enhances the effect of bleomycin. Ascorbic acid (AA) may increase the damage caused by hydrogen peroxide or bleomycin. Caffeine expands toxicity of methotrexate and others drugs. The uncontrolled presence of comutagens in the human environment may increase the negative effects of industrial, medical and other mutagens.

Possible co-mutagenic effects of some common drugs, for instance AA, are of high scientific and practical interest [8]. In series of studies, ambiguous effect of AA on human cells has been revealed [9-12]. As opposed to the animals, AA is not produced in human organism, and its food deficiency contributes to cancer development of gastric, esophagus, oral cavity and cervix origin [13]. There is a contradictory view that vitamins, including $\mathrm{AA}$, are impractical to use as preventive treatment to lower carcinogenic risk [14]. Data on antitumor effect of AA at breast cancer [9], gastric cancer [10], prostate cancer [11] and other tumor localizations have been obtained.

Due to existing environmental situation in post-Chernobyl period, probabilistic development of carcinogenic effect of low dose ionizing irradiation (IR) and oncogenic threat caused by increased level of chromosome changes in cell population, study of AA effect on formation of radiation-induced instability of human somatic cells genome is relevant.

Researchers fairly state that interpretation of data on radioprotective and co-mutagenic effects of some drugs received on experimental animals, including vitamins-antioxidants, is "wrong to extrapolate to human" [3]. Data on nature of AA impact is not always confirmed even in methodically close studies [6].

Ionizing radiation as a global environmental factor, even in small (above background) doses, can cause instability of the human genome, the development of somatic disease, reproductive problems, and increased carcinogenic risk.

However, the influence of co-mutagens on the pattern of radiationinduced effects remains unclear. Nevertheless, there has been a suggestion that the combined effect of co-mutagens and radiation can lead to "the emergence of nonlinear synergistic effects" [15].

*Corresponding author: Mikhailenko V, R.E. Kavetsky Experimental Pathology, Oncology and Radiobiology, NAS of Ukraine, Kiev, Ukraine, Tel: +38 (044) 259-05-93; E-mail: mvmik@yahoo.com

Received May 23, 2015; Accepted May 30, 2015; Published June 06, 2015

Citation: Domina E, Pylypchuk O, Mikhailenko V (2015) The Modifying Effect of Co-Mutagens on the Frequency and Spectrum of RadiationInduced Chromosome Aberrations in Human Cells. Pharm Anal Acta 6: 377. doi:10.4172/21532435.1000377

Copyright: ( 92015 Domina E et al. This is an open-access article distributed under the terms of the Creative Commons Attribution License, which permits unrestricted use, distribution, and reproduction in any medium, provided the original author and source are credited. 
The aims of this study were a) to examine in the comparative aspect the influence of the drugs $\mathrm{Vp}$ and $\mathrm{AA}$ on the frequency and spectrum of radiation-induced chromosomal aberrations in the culture of peripheral blood lymphocytes of healthy individuals; b) to evaluate the effect of different drugs concentrations on cytogenetic damage depending on dose of radiation and stage of mitotic cycle.

\section{Materials and Methods}

In this work, we used the test system of human PBL and metaphase analysis of chromosomal aberrations. Human PBL were analyzed for level and spectrum of chromosomal aberrations, that gives objective information about genome integrity in human somatic cells and are acknowledged to be one of the most sensitive to radiation. This methodology is recommended WHO, IAEA and UNSCEAR for biological indication of the radiation injury of human organism [1618]. Peripheral blood from healthy donors (47 samples) has been cultivated by semi-micro method with some modifications during $52 \mathrm{~h}$. This study was guided by regulations of Helsinki Declaration of the World Medical Association (2008), which provides informed consent of donors for participation in study. Study algorithm is shown graphically in Figure 1.

PBL culture was exposed to radiation in $\mathrm{G}_{0}{ }^{-}$and $\mathrm{G}_{2^{-}}$phases of cell cycle (on 0 and $46 \mathrm{hr}$ of cells incubation correspondingly) on $\gamma$-installation "Rokus" (a source of $\gamma$-rays $\left.{ }^{60} \mathrm{Co}\right)$. The irradiation dose rate was $1.0 \mathrm{~Gy} / \mathrm{min}$, studied doses range $0.3-2.0 \mathrm{~Gy}$. As modifiers of radiation effect, $\mathrm{AA}$ and $\mathrm{Vp}$ have been used. They were added to PBL culture immediately after exposure to radiation in the range of concentrations: AA $-20.0-80.0 \mu \mathrm{g} / \mathrm{ml}$ and $\mathrm{Vp}-1.5-4.0 \mathrm{mg} / \mathrm{ml}$ of blood, respectively.

Cells were cultured according to the standard procedures with modifications, followed by slides preparation and metaphase analysis [19]. PBL were incubated in RPMI 1640 medium("Biowest", France), containing $0,1 \mu \mathrm{g} / \mathrm{ml}$ PHA (M form, Gibco-Invitrogen, USA), 0.5 $\mathrm{ml}$ fetal calf serum ("PPA", Austria), $10 \mathrm{ml}$ gentamicin ("Health", Ukraine) at $37^{\circ} \mathrm{C}$ for $52 \mathrm{~h}$. This procedure designed for cells analysis in the first post-radiation mitosis. Last $3 \mathrm{~h}$ cells were incubated with colcemid ("Biowest", France) at a concentration of $0.5 \mu \mathrm{g} / \mathrm{ml}$ of culture medium, in order to collect cells on metaphase stage. After incubation cells were treated in hypotonic $0.075 \mathrm{M}$ solution of $\mathrm{KCI}$ for 10 minutes at $37^{\circ} \mathrm{C}$. The cell suspension was fixed by cold mixture of ethanol and glacial acetic acid in a ratio of 3:1 (3 times). Slides were stained with $5 \%$ Giemsa solution (Gibco, USA). All slides were coded and scored blindly at $1000 \times$ magnification under oil immersion. Metaphase chromosomes analysis was conducted according to standard procedure [20]. All types of chromosomal aberrations were analyzed. As chromosomal type aberrations were taken into account the acentric fragments (paired and point), centric rings and dicentric chromosomes. The method allows registering a certain part of stable aberrations - reciprocal translocations (approximately 20\% of their total amount). As the chromatid type aberrations were analyzed the acentric fragments and metabolic aberrations.

On each observation, an average 300 metaphases have been analyzed. The differences between group average values were estimated. Error bars represent variations between donors. Statistical analysis of obtained results was performed using of descriptive methods and Student's t-criteria [21].

\section{Results}

It is shown that the AA in the investigated concentration range
(20.0-80.0 $\mu \mathrm{g} / \mathrm{ml})$ does not affect the magnitude of spontaneous level of chromosomal aberrations in the lymphocytes from healthy donors, which corresponds to the average values ( $2.0 \pm 0.86$ on 100 metaphases) . The results are consistent with the data [22] that showed the absence of genotoxic effect of antioxidant vitamins on human lymphocytes.

The analysis of the frequency of chromosome damage induced by irradiation of PBL in the $\mathrm{G}_{0}$-period of cell cycle (dose range 0.3-2.0 Gy) and post-radiation AA exposure in therapeutic concentrations $(20.0$ $\mu \mathrm{g} / \mathrm{ml}$ of blood), showed that radio modifying effect of this drug was ambiguous (Figure 2).

Combined treatment with X-ray radiation in the low dose $(0.3$ Gy) and AA in the therapeutic concentration $(20.0 \mu \mathrm{g} / \mathrm{ml}$ of blood), caused decrease in the total frequency of chromosomal aberrations by 1.5 times as compared to the effect of irradiation. This is consistent with the conclusions of [23], according to which the AA in therapeutic doses exhibits radioprotective properties by utilizing free radicals and improving antioxidant status of cells. Irradiation of PBL in relatively high doses $(2.0 \mathrm{~Gy})$ followed by treatment with AA in the same concentration led to "potentiation of radiation effect" increase in the total frequency of chromosomal aberrations in 1.4 times, thus indicating the co-mutagenic properties of the drug.

This observed potentiation of radiation-induced cytogenetic effect is due to formation of the radiation markers - dicentrics (10/100 metaphases, compared with radiation - 5/100 metaphases) (Figure 3). The formation of metabolic aberrations - dicentrics - requires local double chromosome breaks. Increased yield of this type aberration due to additional treatment with AA can suggest accumulation of primary radiation damage under the influence of this drug. The resulting effects could identify the problem of clastogenic action of AA on the human genome [24].

Special attention is given to the modification of cytogenetic effects in PBL treated with low doses of IR and AA in concentrations exceeding the therapeutic value. An additional post-radiation effect of AA in concentrations of 40.0 and $80.0 \mu \mathrm{g} / \mathrm{ml}$ of blood increased the overall frequency of chromosome aberrations in 1,2-1.4 times when compared to the effect of irradiation with $0.3 \mathrm{~Gy}$, respectively (Figure 4). It may also indicate the co-mutagenic activity of AA in a range of concentrations exceeding by 2 and 4 times the therapeutic value.

Since irradiation in low doses along with chromosome breaks can also induce premutational changes in PBL, the additional potentiating effect of co-mutagens in the high concentrations range may contribute to the structural rearrangements of chromosomes, also due to the inhibition of repair enzymes [25].

We made an estimation of the universal indicator of the functional activity of $\mathrm{T}$ lymphocytes - their ability to proliferate after treatment with mitogenic factors. Analysis of the proliferative activity of PBL under the combined action of irradiation (0.3-2.0 Gy) and AA (20.0 $\mu \mathrm{g} / \mathrm{ml}$ of blood) in $\mathrm{G}_{0}$ - period of the cell cycle showed on Figure 5. The most pronounced inhibition of mitotic activity was observed in cells irradiated at a dose of $2.0 \mathrm{~Gy}$, but exposure to AA in therapeutic concentrations, on the contrary, increased mitotic activity in 2 times, even exceeding the value of intact control (Figure 5). This effect may be caused by removal of the radiation-induced block (delay of mitosis) under the influence of the drug, which reduces the time of primary repair damage. This is confirmed by the increase in the overall frequency of chromosome aberrations under these experimental conditions (Figure 2). 


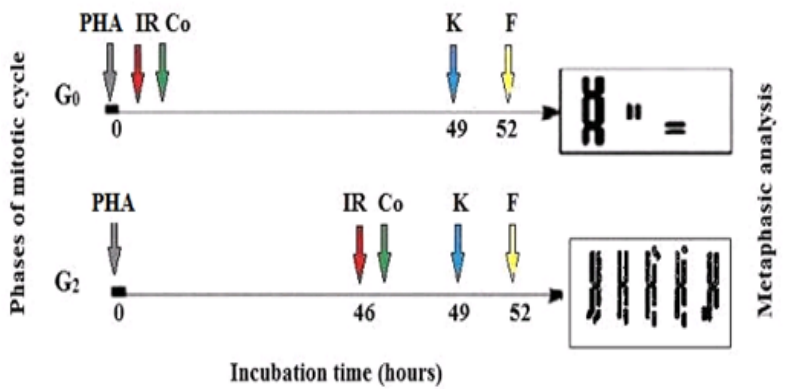

Figure 1: A study algorithm of co-mutagens effect of drugs on the irradiated PBL of healthy donors. PHA - phytohemagglutinin (mitogen); IR - ionizing radiation Co - co-mutagen (verapamil, ascorbic acid); K - colcemid; F - cell fixation.

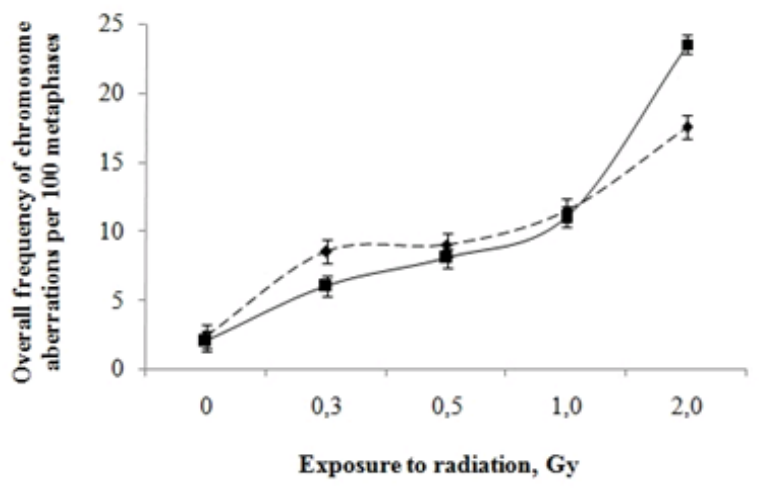

Figure 2: Overall frequency of chromosome aberrations in $\mathrm{PBL}$ treated in vitro with radiation in $\mathrm{G}_{0}$-period of cell cycle and $\mathrm{AA}(20.0 \mu \mathrm{g} / \mathrm{ml}$ of blood). -.- -IR; $\rightarrow-I R+A A$.

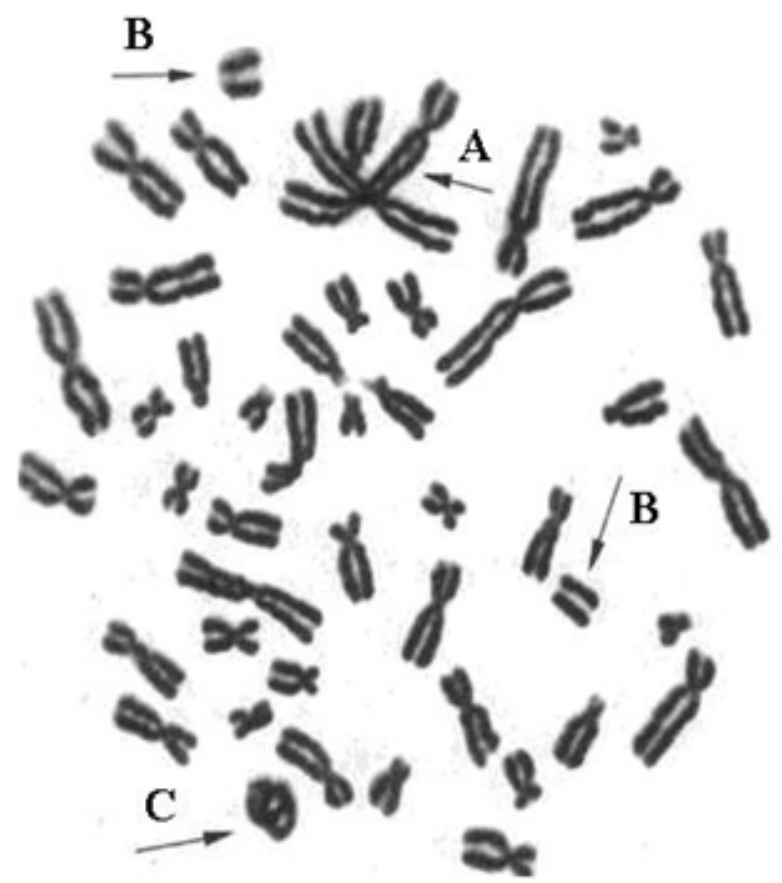

Figure 3: Microphoto of a metaphase plate with dicentric chromosome $(A)$ and pair fragment $(B)$, ring $(C)$ (radiation markers) $(x$ 1000).
The analysis of co-mutagenic activity of the drug and its relationship with the cell radiosensitivity has specific scientific interest. In this regard, we have carried out a study in the most radiosensitive $\mathrm{G}_{2}$-period of the cell cycle of cultured lymphocytes [26]. It is shown that PBL irradiation at $0.3 \mathrm{~Gy}$ dose and AA treatment in therapeutic concentrations, as well as during the experiments in $\mathrm{G}_{0}$ - period, resulted in radioprotective effect with reduced in 1.4 times overall frequency of chromosome aberrations as compared to the effect of irradiation. However, the comutagenic effect in the $\mathrm{G}_{2}$-period appears earlier starting from the dose of $1.0 \mathrm{~Gy}(12.0 \pm 1.1$ and $18.0 \pm 1.4$, respectively) in comparison with the $\mathrm{G}_{0}$-period. The potentiation the co-mutagenic effect in 1.5 times suggests increase of cells radiosensitivity in this period of mitotic cycle (Figures 1 and 6).

Thus, we have studied the regularities of formation of radiationinduced structural rearrangements in PBL chromosomes of healthy individuals under an additional modifying effect of AA. This vitamin, depending on the used concentration for treatment of irradiated cells, can have both radioprotective and co-mutagenic properties. Comutagenic effect of AA was most pronounced after the irradiation of human somatic cells in a relatively high dose, resulted in increased frequency of the radiation markers and depended on the period of the cell cycle. High concentrations of AA potentiated the damaging effect of low doses of IR.

Co-mutagenic effect of AA preferably caused by its impact on the duration of radiation-induced block of mitosis, and thus on the proliferative potential of cells.

The results obtained during the study of co-mutagenic properties of AA, are generally correlated with the cytogenetic data obtained with use of cardiologic drug $\mathrm{Vp}[27,28]$.

The drug $\mathrm{Vp}$ in the range of indicated concentrations had no effect on the spontaneous level of chromosomal aberrations in the lymphocytes of healthy donors. This is consistent with the studies in which the long-term therapy with calcium antagonists does not lead to an increase in the frequency of chromosomal changes [29,30]. PBL irradiation in the range of 0.3-2.0 Gy and additional treatment with $\mathrm{Vp}$ in different concentrations led to an increase in overall frequency of chromosomal aberrations compared to radiation alone. The observed increase in the level of chromosome aberrations correlated with the $\mathrm{Vp}$ concentration (Figure 7).

The spectrum of damage was dominated by the aberrations of chromosomal type, the level of which was also dependent on the concentration of the co-mutagen Vp (Figure 3 and 8). Co-mutagenic effect of $\mathrm{Vp}$ was formed primarily by dicentric chromosomes (for example, at a dose of $0.3 \mathrm{~Gy}, 7.0$ / 100 metaphases) and their level was 2 times higher than after irradiation.

The manifestation of $\mathrm{Vp}$ co-mutagenic properties in human cells exposed to low dose irradiation has particular interest (Figure 9.). In the concentration range of $1.5-2.0 \mathrm{mg} / \mathrm{ml}$ of blood, $\mathrm{Vp}$ did not significantly affect the level of radiation-induced chromosome aberrations. However, its effect in the concentration of $4.0 \mu \mathrm{g} / \mathrm{ml}$ of blood (4-time excess of therapeutic value) potentiated the damaging effect of radiation and enhanced the overall frequency of chromosomal aberrations in about 1.5 times (14.0 \pm 1.12 / 100 metaphases) (Figure 9). The formation of co-mutagenic effect of $\mathrm{Vp}$ has also occurred mainly due to the chromosomal type aberrations (Figures 3 and 10). The $\gamma$-irradiation of cultured PBL in a dose of $1.0 \mathrm{~Gy}$ in the most radiosensitive $\mathrm{G}_{2}$-period of the cell cycle followed by treatment with $\mathrm{Vp}$ in a concentration of $4.0 \mu \mathrm{g} / \mathrm{ml}$ of blood increased 2.4 times genotoxic 
Citation: Domina E, Pylypchuk O, Mikhailenko V (2015) The Modifying Effect of Co-Mutagens on the Frequency and Spectrum of Radiation-Induced Chromosome Aberrations in Human Cells. Pharm Anal Acta 6: 377. doi:10.4172/21532435.1000377

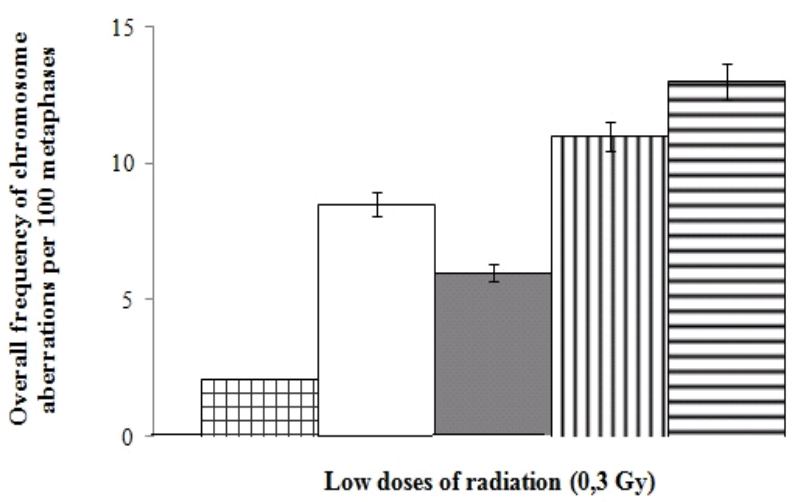

Figure 4: Overall frequency of chromosome aberrations in $\mathrm{PBL}$ treated in vitro with low doses of radiation ( $0.3 \mathrm{~Gy}$ ) in $\mathrm{G}_{0}$-period of cell cycle and different $A A$ concentrations. 田 - control; $\square$ - IR ; $\square$ - IR+ AA $(20.0 \mu \mathrm{g} / \mathrm{ml}$ of blood); $[\mathrm{Il}$ - IR+ AA $(40.0 \mu \mathrm{g} / \mathrm{ml}$ of blood); 目- IR+ AA $(80.0 \mu \mathrm{g} / \mathrm{ml}$ of blood $)$.

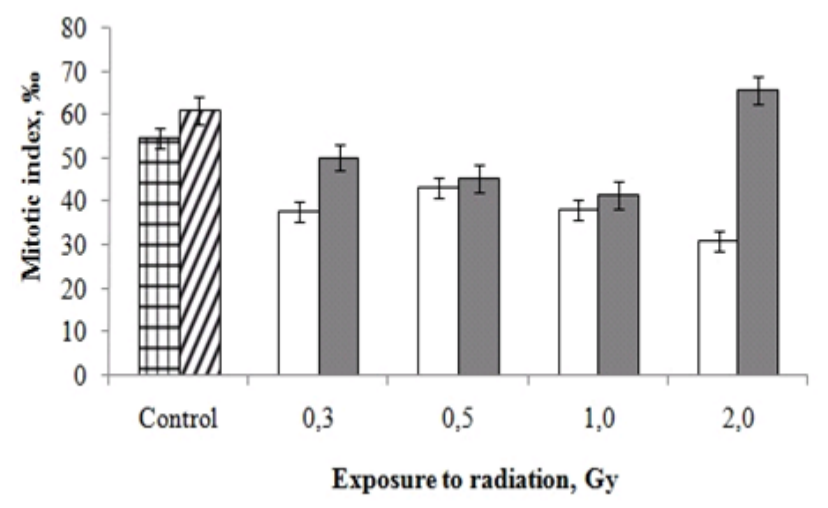

Figure 5: Mitotic activity of PBL treated in vitro with IR (0.3-2.0 Gy) in $\mathrm{G}_{0}$-period of cell cycle and AA $(20.0 \mu \mathrm{g} / \mathrm{ml}$ of blood). 田 - control; $\mathbb{Z}-A A ; \square-I R$; IR+AA.

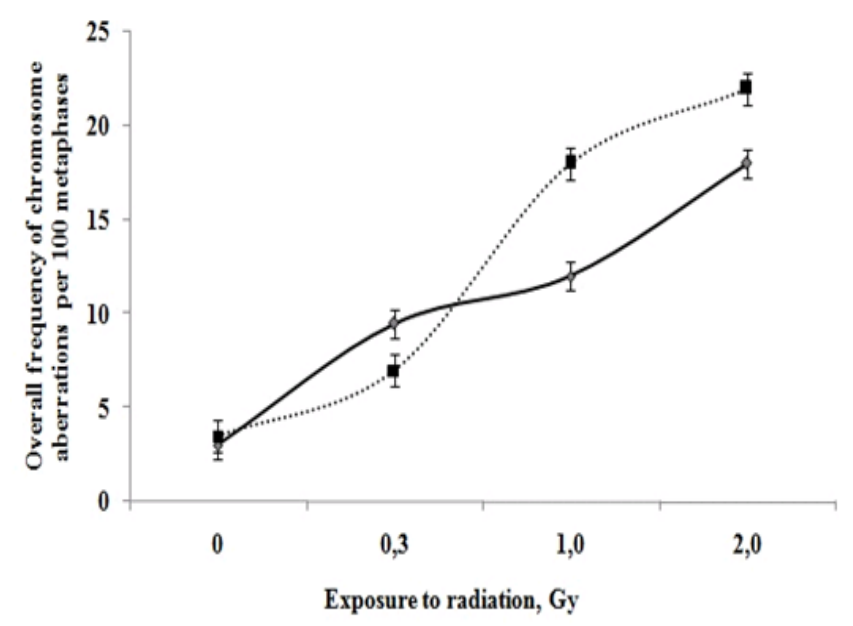

Figure 6: Overall frequency of chromosome aberrations in PBL treated in vitro with radiation in $\mathrm{G}_{2}$-period of cell cycle and $A A(20.0 \mu \mathrm{g} / \mathrm{ml}$ of blood). $\longrightarrow-I R ; \cdots \cdots-\cdots \cdots \cdot$ IR+ AA.

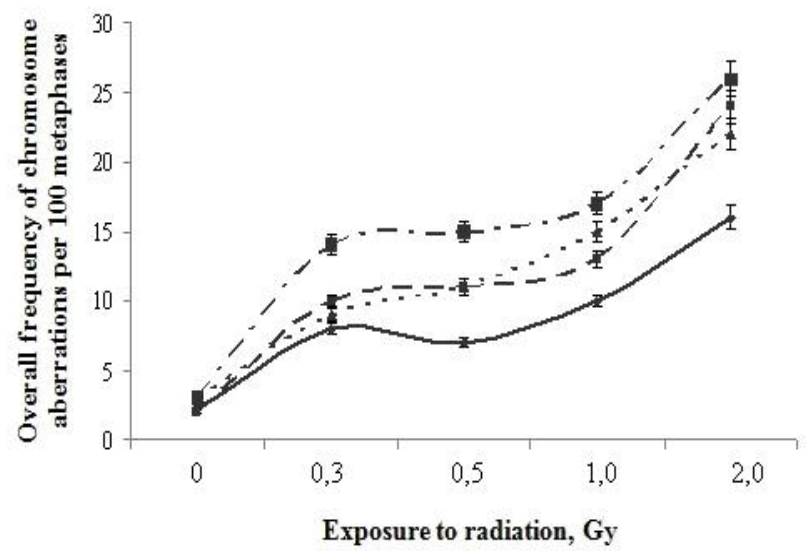

Figure 7: Overall frequency of chromosome aberrations in $\mathrm{PBL}$ treated in vitro with radiation in $\mathrm{G}_{0}$-period of cell cycle and $\mathrm{Vp}$ in different concentrations. - IR; - - - - IR+Vp $(1.5 \mu \mathrm{g} / \mathrm{ml}$ of blood $) ; \ldots \ldots \ldots . . . . . . . . . \mathrm{IR}+\mathrm{Vp}(2.0 \mu \mathrm{g} / \mathrm{ml}$ of blood); - $\rightarrow---I R+V p(4.0 \mu \mathrm{g} / \mathrm{ml}$ of blood $)$.

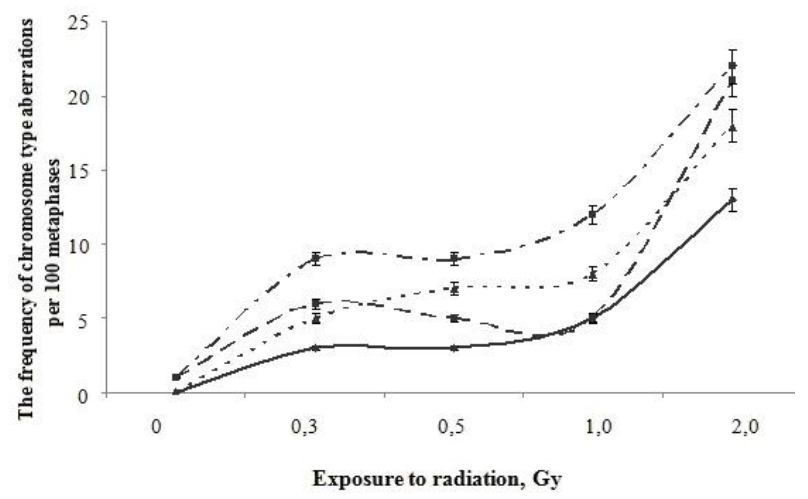

Figure 8: The frequency of chromosome type aberrations in PBL treated in vitro with radiation in $\mathrm{G}_{0}$-period of cell cycle and $\mathrm{Vp}$ in different concentrations. $\longrightarrow$ - IR; _ - - - - IR+Vp $(1.5 \mu \mathrm{g} / \mathrm{ml}$ of blood $) ; \ldots \ldots \ldots . . . . . . . . . \mathrm{IR}+\mathrm{Vp}(2.0$ $\mu \mathrm{g} / \mathrm{ml}$ of blood $) ;-\rightarrow--$ IR+ $\mathrm{Vp}(4.0 \mu \mathrm{g} / \mathrm{ml}$ of blood $)$.

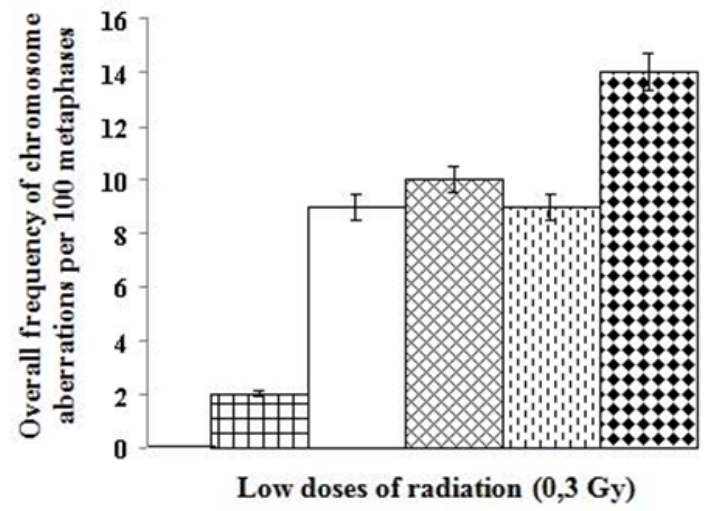

Figure 9: Overall frequency of chromosome aberrations in $\mathrm{PBL}$ treated in vitro

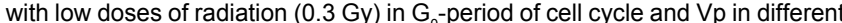

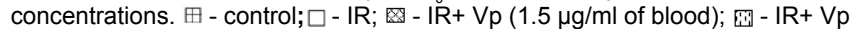
$(2.0 \mu \mathrm{g} / \mathrm{ml}$ of blood); $\mathrm{s}-\mathrm{IR}+\mathrm{Vp}(4.0 \mu \mathrm{g} / \mathrm{ml}$ of blood $)$. 
damage as compared to the effect of irradiation.

It has been shown that $\mathrm{Vp}$ at a concentration of $1.5 \mu \mathrm{g} / \mathrm{ml}$ of blood had no effect on the mitotic activity of the lymphocytes (Figure 11). However, after combined influence of radiation ( $0.3 \mathrm{~Gy})$ and Vp we observed $30 \%$ inhibition of cells proliferative capacity in comparison with the effect of radiation and intact control. Elevation of $\gamma$-irradiation dose up to 2.0 Gy combined with $\mathrm{Vp}$ treatment did not change the level of PBL mitotic activity.

Earlier, a pilot study that used the analysis of chromosomal aberrations in bone marrow cells of mice was established the effect of calcium channel blockers - diltiazem and nifedipine on the mutagenic effects of dioxide and cyclophosphamide [31]. These drugs exhibited co-mutagenic activity by potentiating the chromosomes damage by mutagens in 1.3 and 2.9 times depending on the dose. Moreover, co-mutagenic effects of the drugs were most pronounced after their repeated administration.

$\mathrm{Vp}$ and its analogues enhanced the cytotoxic effects of some antibiotics [32], including the frequency of microkernels in human blood lymphocytes treated with erythromycin [33]. The researchers explain the mechanism of co-mutagenic effect of Vp in terms of "the theory of accumulation", according to which the calcium antagonists inhibited the excretion of cytotoxins from the cells, thereby increasing their potential mutagenic effect $[34,35]$.

In accordance with the hypothesis [36], an increase in the level of intracellular calcium is associated with DNA damage due to oxidative stress. However, until now the influence of $\mathrm{Vp}$ on the formation of genetic lesions in irradiated human cells, in particular immunocompetent T-lymphocytes, that are responsible for the antitumor defense of the organism, stays unexplained [37].

The lack of conclusive data related to characteristics and mechanisms of co-mutagenic effects manifestation makes it impossible to estimate their actual genetic risk to humans and develop ways to correct the possible negative consequences.

DNA double-strand breaks (DSB) are critical damages and incorrect repair or absence of repair is involved in the formation of chromosomal aberrations. Homologous recombination and DNA non homologous end-joining represent the two major DSB repair mechanisms in mammalian cells [38]. Elevated level of chromosomal aberrations in irradiated cells induced by co-mutagens may be caused by increased formation of DSB and/or aberrant processing of DSB by inhibited or altered repair system.

\section{Conclusions}

We have studied qualitative and quantitative features of the formation of radiation-induced chromosomal aberrations in the most radiosensitive cells (T-lymphocytes of peripheral blood) of healthy donors exposured to the drugs ( $\mathrm{Vp}, \mathrm{AA}$ ) with co-mutagenic properties.

The intensity of co-mutagenic effects depended on the concentration of the drugs, the absorbed dose of IR and the extent of cell radiosensitivity. High concentrations of co-mutagens potentiated the damaging effect of low (above background) doses of radiation.

The obtained results should be taken into consideration when prescribing drugs with co-mutagenic activity to the patients that were in contact with the sources of IR, including those living in the radiation-contaminated areas.

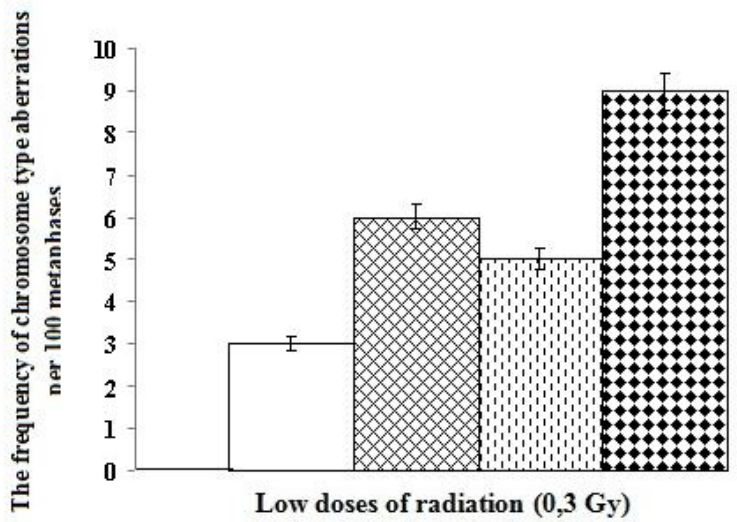

Figure 10: The frequency of chromosome type aberrations in PBL treated in vitro with low doses of radiation $(0.3 \mathrm{~Gy})$ in G0-period of cell cycle and $V p$ in different concentrations. - IR; - IR+Vp $(1.5 \mu \mathrm{g} / \mathrm{ml}$ of blood $)$; - IR+Vp $(2.0 \mu \mathrm{g} /$ $\mathrm{ml}$ of blood); - IR+Vp $(4.0 \mu \mathrm{g} / \mathrm{ml}$ of blood $)$.

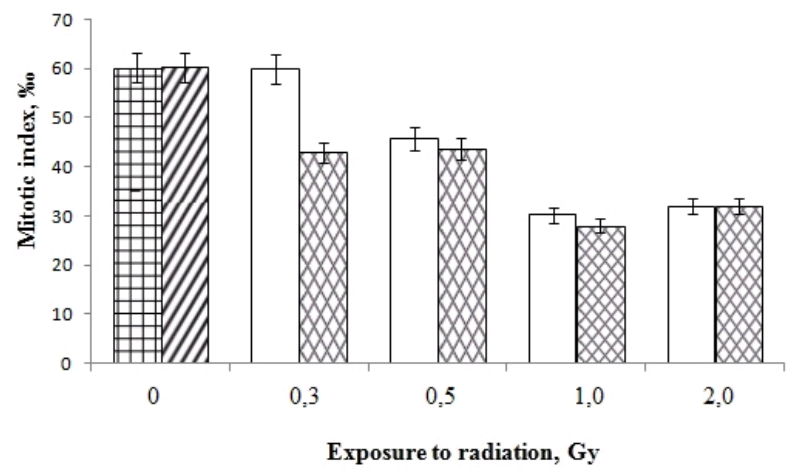

Figure 11: Mitotic activity of PBL treated in vitro with IR (0,3-2,0 Gy) in G0period of cell cycle and $\mathrm{Vp}(1.5 \mu \mathrm{g} / \mathrm{ml}$ of blood $)$ on $\mathrm{PBL}$. - control; - $\mathrm{Vp}$; IR; - IR+Vp.

\section{Conflict of Interests}

The authors declare that there is no conflict of interests regarding the publication of this manuscript.

\section{References}

1. Petin VG, Zhurakovskaya GP, Komarova LN (2012) Radiobiological synergistic ways in the biosphere, Moscow, GEOS: 219.

2. Diomina EA, Chekhun VF (2013) Experimental validation of prevention of the development of stochastic effects of low doses of ionizing radiation based on the analysis of human lymphocytes chromosome aberrations, Experimental Oncology 35: 65-68.

3. Durnev AD, Seredenin DB (1998) Mutagens: screening and pharmacological prevention of exposure, Moscow, Medicine: 328

4. Taylor JH, Haut WF, Tung J (1962) Effects of fluorodeoxyuridine on DNA replication, chromosome breakage, and reunion, Proc Natl Acad Sci U S A 48:190.

5. Luchnik NV (1978) The Phenomenon of False Mutagenesis, Abstracts of $V$ Soviet-American Symposium. Moscow 23

6. Durnev AD, Seredenin SB (2003) Co-mutagenesis as new vistas in genotoxicology. Bull Exp Biol Med 135: 513-520.

7. Molento MB, Lifschitz A, Sallovitz J, Lanusse C, Prichard R (2004) Influence of verapamil on the pharmacokinetics of the antiparasitic drugs ivermectin and moxidectin in sheep, Parasitology Research 92: 121-127. 
Citation: Domina E, Pylypchuk O, Mikhailenko V (2015) The Modifying Effect of Co-Mutagens on the Frequency and Spectrum of Radiation-Induced Chromosome Aberrations in Human Cells. Pharm Anal Acta 6: 377. doi:10.4172/21532435.1000377

Page 6 of 6

8. Svergun VT and Koval AN (2013) Dynamics of changes in the content of ascorbic acid in rats with external irradiation, International Conference Radiation, ecology and Technosphere Minsk: Institute of Radiology 143-144.

9. Cha J, Roomi MW, Ivanov V, Kalinovsky T, Niedzwiecki A, et al. (2013) Ascorbate supplementation inhibits growth and metastasis of B16FO melanoma and $4 \mathrm{~T} 1$ breast cancer cells in vitamin C-deficient mice. International journal of oncology 42: 55-64.

10. Nagappan A, Park KI, Park HS, Kim JA, Hong GE, et al. (2012) Vitamin C induces apoptosis in AGS cells by down-regulation of 14-3-3ï $f$ via a mitochondrial dependent pathway. Food Chem 135: 1920-1928.

11. Surapaneni KM, Ramana V (2007) Erythrocyte ascorbic acid and plasma vitamin $E$ status in patients with carcinoma of prostate. Indian Journal of Physiology and Pharmacology 51: 199-202.

12. Kapoor S (2013) Vitamin C: attenuating effect on growth and proliferation in systemic malignancies. Exp Oncol 35: 72.

13. Mirvish SS (1986) Effects of vitamins $C$ and $E$ on $N$-nitroso compound formation, carcinogenesis, and cancer. Cancer 58: 1842-1850.

14. Zaridze DG (2009) Cancer prevention. Guide for physicians Moscow 224.

15. Petin VG and Synzynys BI (1998) The combined effect of environmental factors on biological systems Obninsk. IATE 74 .

16. Backton Eds K, Evans H (1976). - Geneva: WHO, Method of human chromosome aberration analysis 64

17. Biological dosimetry (1986) chromosomal aberrations analysis for dose assessment. Technical Reports series N 260 Vienna: Int. Atom. Energy Agency -69 .

18. Farai IP, Ademola JA (2005) Radium equivalent activity concentrations in concrete building blocks in eight cities in Southwestern Nigeria. J Environ Radioact 79: 119-125.

19. Cytogenetic Dosimetry (2011) Applications in Preparedness for and Response to Radiation Emergencies - Vienna: IAEA 232.

20. Mitelman F Basel (1995) International System of Cytogenetic Nomenclature for Acquired Chromosome Aberrations 120.

21. Klyushin DA, Petunin YI (2008) Evidence-based medicine. Application of statistical methods Moscow, Dialectics 320.

22. Durnev AD, Sidneva ES, Zhanataev AK, Nikitina VA, Bochkov NP (2007) The protective action of vitamins in induced mutagenesis. Vestnik Rossiisko akademii meditsinskikh nauk/Rossiiskaia akademiia meditsinskikh nauk 7 : 6-13.

23. Jagetia GC (2007) Radioprotective potential of plants and herbs against the effects of ionizing radiation. Journal of Clinical Biochemistry and Nutrition 40 : 74-81.

24. Konopacka M, Rogolinski J (2011) Clastogenic effects in human lymphocytes exposed to low and high dose rate X-ray irradiation and vitamin C. Nukleonika 56: 253-257.
25. McNeill DR, Wong HK, Narayana A, Wilson DM (2007) Lead promotes abasic site accumulation and co-mutagenesis in mammalian cells by inhibiting the major abasic endonuclease Ape1. Molecular carcinogenesis 46: 91-99.

26. Domina (2005) Chromosomal radiosensitivity of human peripheral blood lymphocytes and the mitotic cycle. Security problems and Chernobyl nuclear power plants. Scientific and Engineering. collection. Chernobyl 3: 80-86.

27. Domina, Pylypchuk OP (2012) Cytogenetic aspects of co-mutagenesis. Archive for Clinical and Experimental Medicine 21: 149-151.

28. Pylypchuk OP, Domina (2013) C-mutagenesis and effects of low doses of ionizing radiation. Materials International Forum Radioecology-Chernobyl. Fukushima and consequences, Kyiv 203-205.

29. Andreassi MG, Picano E, Del Ry S, Petrozzi L, Giannessi D, et al. (1999) Effects of chronic long-term therapy with calcium antagonists on cytogenetic damage in humans. Journal of hypertension 17: 843-846.

30. Milosevic-Djordjevic O, Grujicic D, Joksic G, Marinkovic D (2011) In vitro evaluation of the genotoxicity of ritodrine and verapamil in human lymphocytes. Human \& experimental toxicology 30: 398-405

31. Kulakova AV, Zhanatan AK, Durnev AD (2007) Research co-mutagenic activity of diltiazem and nifedipine. Materials of III Congress of the Russian pharmacologists 23-27.

32. Toffoli G, Simone F, Corona G, Raschack M, Cappelletto B, et al. (1995) Structure-activity relationship of verapamil analogs and reversal of multidrug resistance. Biochemical pharmacology 50: 1245-1255.

33. Grujicic D, Milosevic-Djordjevic, Arsenijevic S,Marinkovic D (2008) Treatment of pregnant women with a beta mimetic and verapamil increases the micronucle frequency in umbilical cord blood lymphocytes. The Tohoku J Exp Med 215: 363-371.

34. Scheid W, Weber J, Röttgers U, Traut H (1991) Enhancement of the mutagenicity of anticancer drugs by the calcium antagonists verapamil and fendiline. Arzneimittel-Forschung 41: 901-904

35. Liu Y, Huang H (1997) Involment of calcium-dependent protein kinase $C$ in arsenite-induced genotoxicity in Chinese hamster ovary cells. Journal of Cellular Biochemistry 64: 423-433.

36. Halliwell B, Aruoma OI (1991) DNA damage by oxygen-derived species. Its mechanism and measurement in mammalian systems. FEBS Lett 281: 9-19.

37. Grinevich Y, Domina (2006) Immune and Cytogenetic Effects of Dense and Rare lonizing Radiation Zdorovya 200.

38. Jeggo PA, Löbrich M (2006) Contribution of DNA repair and cell cycle checkpoint arrest to the maintenance of genomic stability. DNA Repair (Amst) 5: 1192-1198 